\title{
Uma história das práticas letradas: homenagem a Andrea Daher
}

\author{
Roger Chartier ${ }^{*}$ \\ ${ }^{1}$ Collège de France, Paris - França \\ Hélio de Seixas Guimaräes ${ }^{2 * *}$ \\ ${ }^{2}$ Universidade de São Paulo, São Paulo/SP - Brasil \\ Marcello Moreira ${ }^{3 * * *}$
}

${ }^{3}$ Universidade Estadual do Sudoeste da Bahia, Vitória da Conquista/BA - Brasil

Em 4 de junho de 2019, Andrea Daher recebeu o título de professora emérita do Instituto de História da Universidade Federal do Rio de Janeiro. Alguns meses antes da solenidade, em agosto de 2018, foi feita uma homenagem ao seu trabalho, intitulada "Jornada de Estudos sobre oralidade e escrita. Homenagem a Andrea Daher", no Saláo Nobre do mesmo Instituto, contando com a participação de colegas da História, das Ciências Sociais e das Letras.

Três dessas homenagens são hoje publicadas aqui, num único dossiê: a de Roger Chartier (I), a de Hélio de Seixas Guimarães (II); e a de Marcello Moreira (III). Foram mantidas as características orais desses discursos, publicados tais como foram apresentados, a que foram acrescidas notas bibliográficas.

Por fim, encontra-se ainda, neste dossiê, o discurso proferido por Andrea Daher na cerimônia de sua emerência (IV), tornando coerentes e plenas de sentido as homenagens prestadas que o precedem.

DOI: http://dx.doi.org/10.1590/2237-101X02004101

* Roger Chartier é professor emérito do Collège de France, Paris - França. Email: roger.chartier@ehess.fr. http://orcid.org/0000-0002-6008-9241.

**Hélio de Seixas Guimarães é professor da Universidade de São Paulo, São Paulo/SP - Brasil. Email: hsg@ usp.br. https://orcid.org/0000-0002-2054-2689.

***Marcello Moreira é professor da Universidade Estadual do Sudoeste da Bahia, Vitória da Conquista/BA Brasil. Email: moreira.marcello@gmail.com. https://orcid.org/0000-0001-6827-2772. 
Le mot "retraite" sonne mal en français, et plus mal encore à propos d'Andrea Daher dont l'énergie intellectuelle et l'inventivité historiographiques sont aujourd' hui ce qu'elles étaient lors de nos premières rencontres, lorsqu'elle préparait à l'Ecole des hautes études en sciences sociales sa thèse de doctorat, devenue un livre classique de la bibliothèque consacré au Brésil de la première colonisation. La rencontre d'aujourd'hui me fait descendre dans ma mémoire, comme disait Borges, et me fait souvenir des nombreux séminaires que nous avons partagés, depuis le "petit séminaire" du 54 Boulevard Raspail, chaque jeudi à 14 heures, où se nouèrent tant d'amitiés qui durent encore. Dans les années qui suivirent, notre compagnonnage intellectuelle se poursuivit des deux côtés de l'Atlantique, grâce aux séminaires que je donnais à l'UFRJ à l'invitation d'Andrea, grâce aussi à sa présence annuelle à Paris où, entre 2010 et 2014, elle occupa la Chaire Sergio Buarque de la Maison des Sciences de l'Homme et de l'Université Paris IV-Sorbonne. Les séminaires qu'elle a donnés dans plusieurs institutions françaises comme la publication de ses livres en français (Les Singularités de la France équinoxiale en 2002, L'Oralité perdue en 2015) en ont fait un membre à part entière de la communauté des historiens qui travaillent en France.

A relação entre oralidade e escrita é tema presente em todas as obras de Andrea Daher. Seu trabalho histórico sempre se dedicou à exploração da articulação que liga as modalidades da transcrição da palavra viva e as formas de transmissão oral da palavra escrita. É esta a problemática que enfatiza na apresentação do livro que organizou recentemente: Oral por escrito. Escreve Andrea Daher: "Por um lado, em dispositivos editoriais e 'índices de oralidade' depositados no escrito, buscaram-se as adaptaçôes necessárias à performance oral, em geral à leitura em voz alta; ou, no sentido inverso, a transcrição da palavra oral no texto. Por outro, em materiais normativos ou descritivos - desde os tratados de retórica aos textos literários - que veiculam representaçôes de práticas letradas que implicam a oralidade - recitaçáo, canto, leitura em voz alta, etc. - foi possível dar conta das modalidades orais de transmissão do escrito". ${ }^{1}$

Semelhante tensão vincula-se com os argumentos de fundo do trabalho de Andrea Daher: a transcrição da fala dos índios do Brasil nos relatos franceses, desde Jean de Léry até os Capuchinos do Maranhão, e sua ausência no corpus textual jesuítico português; o uso da própria língua dos índios ou da língua geral na catequese e na conversão, e isso

\footnotetext{
* Estes termos iniciais do discurso de Roger Chartier foram mantidos expressamente em francês a pedido do próprio autor, que preferiu que "o primeiro parágrafo permanecesse em francês, como uma ilustração da trajetória e da obra de Andrea Daher".

${ }^{1}$ DAHER, Andrea (Org.). Oral por escrito. A oralidade na ordem da escrita, da retórica à literatura. Chapecó; Argos; Florianópolis: Editora UFSC, 2018, p. 11.
} 
não somente pela exigências da comunicação, porém por pressupostos teológicos e políticos essenciais na perspectiva apostólica. A relação paradoxal entre a evangelização em línguas indígenas e o "imperialismo linguístico" português ou castelhano fundamenta a observação que liga a gramaticalização das línguas americanas, "de um lado, as exigências teológico-políticas da colonização e, de outro, a reflexão letrada sobre a hierarquia linguística encabeçada pela próprias línguas nacionais". ${ }^{2}$

A reflexão de Andrea Daher introduz o tema fundamental da irredutibilidade das práticas, inclusive as práticas orais, ao discurso escrito. A perspectiva é essencial, mas não deve fazer esquecer sua dificuldade teórica. Pierre Bourdieu a formulou graças à oposição entre o senso prático e a razão "escolástica”, que é a lógica do conhecimento distanciado. Escreveu na introdução do seu livro $O$ senso prático: "Uma das contradiçóes práticas da análise científica de uma lógica prática reside no fato paradoxal de que o modelo mais coerente e também mais econômico, aquele que explica de maneira mais simples e mais sistemática os fatos observados, não é o princípio das práticas que ele explica”. ${ }^{3}$ Para Bourdieu, as práticas "têm por princípio não regras conscientes e constantes, mas esquemas práticos, opacos a si mesmos, sujeitos a variar segundo a lógica da situação, o ponto de vista, quase sempre parcial, que ela impóe". " Daí as contradiçôes, as ambivalências, as ambiguidades que caracterizam a lógica do rito, do discurso oral, ou mais geralmente do senso prático. Daí o paradoxo do projeto historiográfico, mas também sociológico ou antropológico, que traduz na lógica da escrita os procedimentos de uma outra lógica, uma lógica prática, que por definição escapa à apreensão teórica. Ainda que as práticas do passado não sejam, na maior parte das vezes, acessíveis a não ser através dos textos que as representam ou organizam, prescrevem ou proscrevem, isto não implica, contudo, a confusão entre as duas lógicas: a lógica que governa a produção, a transmissão e a recepção da escrita e a lógica que regula comportamentos e açóes.

Essa tensão tem um papel fundamental. Como observou Jack Goody no seu livro A domesticação da mente selvagem, a introdução da escrita nas sociedades - tanto antigas como contemporâneas, tanto europeias como coloniais - permite operações intelectuais impossíveis numa cultura exclusivamente oral, tais como a fixação e a conservação dos textos, a separação entre o enunciado e a enunciação, a possibilidade de classificar, ordenar e consultar as informaçóes organizadas em listas, tabelas e fórmulas ${ }^{5}$. A escrita modifica tanto o sistema de arquivamento e comunicação quanto as operaçóes cognitivas. Estabelece uma "razão gráfica" (segundo o título da tradução francesa do livro de Goody) que "transfere a língua do domínio auditivo para o domínio visual e possibilita um tipo diferente de inspeção, a reordenação e o refinamento não só de frases, mas também de palavras individuais.

\footnotetext{
${ }^{2}$ DAHER, Andrea. A oralidade perdida. Ensaios de história das práticas letradas. Rio de Janeiro: Civilização Brasileira, 2012, p. 96.

${ }^{3}$ BOURDIEU, Pierre. O senso prático. Petrópolis: Editora Vozes, 2009, p. 26.

${ }^{4}$ Ibidem, p. 27.

${ }^{5}$ Cf. GOODY, Jack. A domesticação da mente selvagem. Petrópolis: Editora Vozes, 2012.
} 
Os morfemas podem ser retirados do corpo da frase, do fluxo do discurso oral e postos de lado como unidades isoladas, capazes não só de serem ordenadas dentro de uma frase, mas de serem ordenadas fora dessa moldura, em que elas aparecem em um contexto muito diferente e extremamente 'abstrato'". ${ }^{6}$ Mas, ao mesmo tempo, este "processo de descontextualização" operado pela escrita deve alertar contra a alteração da oralidade que implica sua "domesticação" por uma lógica escrita cujas oposições binárias e tábulas sistemáticas ignoram as ambivalências e incertezas da significação dos mesmos elementos (as cores, por exemplo), o que depende inteiramente do contexto de sua mobilização.

Os historiadores se apoderaram da oposição entre sociedades sem escrita e sociedades com escrita proposta por Goody não só para caracterizar os procedimentos específicos da tradição oral, mas também para matizar sua radicalidade. Identificaram nas sociedades localizadas de cada um dos lados do Atlântico a duradoura coexistência entre as práticas da oralidade e as múltiplas formas da presença da escrita. A transcriçẫo das palavras vivas, por um lado, e a transmissáo oral da palavras escritas, por outro, foram e são as duas modalidades essenciais do cruzamento entre práticas fortemente associadas. $\mathrm{Na}$ escolarização, esta coexistência explica a persistência da leitura em voz alta, no momento mesmo da afirmação de um modelo visando a facilitar uma leitura mental e silenciosa, capaz de apoderar-se de textos desconhecidos - e não só de reconhecer textos já conhecidos e aprendidos oralmente. Fora da escola, a fixação escrita de gêneros próprios da tradição oral como os contos ou os sermóes e, ao contrário, a leitura em voz alta ou a recitaçáo de cor dos textos impressos evidenciam as trocas permanentes entre as práticas próprias das duas culturas.

Comecei esta palestra com a distinção entre a transcrição da oralidade e a transmissão oral da escrita. Queria matizar esta oposição com uma análise de três dispositivos que vinculam estreitamente transcrição e transmissão, oralidade e escrita, tal como no ensaio de D. F. McKenzie, "Speech-Manuscript-Print", ou nos livros de Fernando Bouza. ${ }^{8}$ O primeiro são as representaçôes literárias das práticas da oralidade: recitação, canto, leitura em voz alta. Trata-se de constituir o corpus dessas oralidades silenciosas que determinados textos dão a ouvir na ficção da escrita. É o caso do conto narrado por Sancho a Dom Quixote, no capítulo XX da Primeira parte da história9. A descrição mostra, com uma grande acuidade, a distância que separa o modo de narrar de Sancho e as expectativas de leitor de Dom Quixote. Sancho narra multiplicando as retomadas, os retrocessos, as oraçóes relativas e interca-

\footnotetext{
${ }^{6}$ Ibidem, p. 90.

${ }^{7}$ McKENZIE, D.F. "Speech - Manuscript - Print". In: Making Meaning: "Printers of the Mind" and other Essays. Edited by Peter D. McDonald and Michael F. Suarez, S.J. Amherst: University of Massachussetts Press, 2002.

${ }^{8}$ Cf. BOUZA, Fernando. Corre manuscrito. Una historia cultural del Siglo de Oro. Madrid: Marcial Pons, 2001; e . Palabra e imagen en la Corte. Cultura oral y visual de la nobleza en el Siglo de Oro. Madri: Abada Editores, 2003.

${ }^{9}$ Cf. CERVANTES, Miguel de. O engenhoso fidalgo D. Quixote de la Mancha. Tradução de Sérgio Molina. São Paulo: Editora 34, 2010, p. 261-264.
} 
ladas; interrompe constantemente sua história com referências à situação na qual se encontra com Dom Quixote. Este espera uma narrativa linear, sem retomadas, sem repetiçôes, sem digressóes. Cervantes representa assim a distância que diferencia os modos de dizer e as maneiras de ler (ou de ouvir ler). Sancho narra segundo o hábito de narrar os contos em sua aldeia. Mas Dom Quixote se impacienta ao ouvir essa fala táo estranha frente à relaçáo do leitor com um texto escrito, fixo, linear.

Do mesmo modo, no capítulo V de seus Propos rustiques, Noël Du Fail pôe em cena a maneira como um rico camponês, Robin Chevet, narra antigos contos diante de seus familiares reunidos. ${ }^{10}$ Os traços que Du Fail escolhe para caracterizar essa recitação são os mesmos que Cervantes utilizara para caracterizar a maneira como Sancho narra os contos: as interpelaçôes da audiência, as digressôes, as repetiçôes. Essa primeira direção de investigação considera que as representaçôes literárias das práticas da oralidade podem designar adequadamente os procedimentos que as governam para produzir efeitos de oralidade na escrita.

Uma segunda perspectiva reconhece os "índices de oralidade", tais como definidos por Paul Zumthor: "Por índices de oralidade, entendo tudo o que, dentro de um texto, informa-nos sobre a intervenção da voz humana em sua publicação, quer dizer, na mutação pela qual esse texto passou, uma ou mais vezes, de um estado virtual à atualidade, e existiu na atenção e na memória de um certo número de indivíduos". ${ }^{11}$ Esses índices de oralidade, depositados no interior dos textos, não são representaçôes de práticas da oralidade, mas dispositivos, explícitos ou implícitos, que atribuem aos textos destinatários que leem em voz alta ou que ouvem a leitura. Eles podem ser indiscutíveis: quando, por exemplo, uma nota musical ou uma referência a uma canção conhecida indica que o texto deve ser cantado. É o caso, por exemplo, das "broadside ballads", na Inglaterra nos séculos XVI e XVII. Eles podem ser simplesmente prováveis, como no caso dos textos que se dirigem a um público duplo: os que lerão e os que ouvirão ler. Em todas as línguas europeias, um par de verbos indicava esta dupla recepção: to read e to hear, ler e escuchar, ler e ouvir, lire e oür. Os prólogos, as advertências aos leitores, os títulos de capítulos (por exemplo, o capítulo LXVI da Segunda parte de Dom Quixote: "Que trata do que verá quem o ler, ou do que ouvirá quem o ouvir ler") indicam com muita frequência essa dupla destinação e dupla circulação do texto. ${ }^{12}$

Outros índices, inscritos na estrutura formal das obras, podem igualmente sugerir a destinação oral dos textos. Muitas obras antigas, a começar pelas maiores, como Dom Quixote, são organizadas em capítulos curtos, perfeitamente adaptados às necessidades de "perfor-

${ }^{10}$ Cf. DU FAIL, Noël. Propos rustiques de Maistre Leon Ladulfi Champenois. In: Conteurs français du XVIe siècle, Textes présentés et annotés par Pierre Jourda, Gallimard, Bibliothèque de la Pléiade, 1965 [1548], p. 620-621.

${ }^{11}$ ZUMTHOR, Paul. A letra e a voz. A "literatura” medieval. São Paulo: Companhia das Letras, 1993, p. 35-36.

${ }^{12}$ FRENK, Margit. Entre la voz y el silencio. La lectura en tiempos de Cervantes. México: Fondo de Cultura Económica, 2005. 
mance" oral, que supôe uma duração limitada para não cansar a audiência e a impossibilidade de memorizaçáo de uma intriga demasiado complexa. Os capítulos breves, que são unidades textuais, podem ser assim pensados como unidades de leitura, fechadas sobre si mesmas e disjuntas. ${ }^{13} \mathrm{~A}$ divisão do texto em unidades menores, a multiplicação de episódios autônomos são índices dessa adaptação das obras a uma modalidade essencial de sua transmissão. O mesmo acontece sem dúvida com as coletâneas de novelas, em que coincide a enunciação fictícia posta em cena (que imagina a reunião de vários contadores em um lugar fechado) com as condiçóes reais de sua circulação (pela leitura em voz alta).

A estreita relação entre transcrição e transmissão da oralidade se expressa também numa terceira perspectiva: o estudo da pontuação, partindo da hipótese da passagem, entre os primeiros séculos da Idade Moderna e os tempos contemporâneos, de uma pontuação de oralização que indica as pausas a uma pontuação gramatical e sintática. ${ }^{14}$ Verificar essa hipótese levanta uma questão preliminar: a quem se deve atribuir as formas gráficas das ediçôes antigas? Isso significa discutir, de maneira mais ampla, o problema das diferentes intervençôes que dão forma material aos textos impressos. Segundo as diversas tradiçôes da crítica textual, a ênfase náo é posta sobre o momento do processo de edição, nem mesmo sobre os atores envolvidos nesse processo.

Para a bibliografia, em sua definição clássica, as escolhas gráficas devem-se aos operários tipógrafos. A pontuação é considerada, a exemplo de outras variaçóes, como resultante, não do autor que escreveu ou dos copistas que estabeleceram o manuscrito utilizado na tipografia, mas dos hábitos dos operários que compuseram as páginas do livro impresso.

$\mathrm{Na}$ perspectiva da filologia, o essencial reside na preparação do manuscrito para a composição, tal como operada pelos corretores ou "copy editors", que acrescentam capitais, acentos e pontuação, normalizam a ortografia, fixam as convençóes gráficas. ${ }^{15}$ Se este é o resultado de um trabalho ligado à oficina tipográfica e ao processo de publicação, as escolhas quanto à pontuação não são atribuídas aos operários tipógrafos, mas aos letrados (clérigos, detentores de títulos universitários, professores) empregados pelos editores para garantir a maior correção possível de suas edições.

O papel dos corretores na fixação gráfica e ortográfica da língua foi muito mais decisivo do que as propostas de reforma da ortografia feitas pelos escritores que queriam impor uma "escrita oral", inteiramente comandada pela maneira de dizer. ${ }^{16}$ Como efeito, na França do século XVI, é grande a distância entre a moderação das soluçôes escolhidas para as edi-

${ }^{13}$ Cf. NELSON, William. "From 'Listen, Lording' to 'Dear Reader", University of Toronto Quarterly. A Canadian Journal of the Humanities, Vol. XLVI, n' 2, 1976-1977, p. 110-124.

${ }^{14}$ Cf. CHARTIER, Roger. "Pausas e tônicas". In: A mão do autor e a mente do editor. Traduçáo George Schlesinger. São Paulo: Editora Unesp, 2013, p. 153-173.

${ }^{15}$ Cf. GRAFTON, Anthony. The Culture of Correction in Renaissance Europe. Londres: British Library, 2011.

${ }^{16}$ Cf. CATACH, Nina. L'Orthographie française à l'époque de la Renaissance (auteurs, imprimeurs, ateliers d'imprimerie). Genebra: Librairie Droz, 1968. 
ções impressas e a ousadia das reformaçóes sugeridas pelos autores da Pléiade. Ronsard, por exemplo, propóe a supressão de toda ortografia supérflua (isto é, todas as letras que não são pronunciadas), a transformação da grafia das palavras a fim de aproximá-la do modo como são pronunciadas (por exemplo, roze, kalité, Franse, langaje, etc.) e a introdução em francês do $l l$ ou do $n$ espanhol, para marcar bem a pronúncia de palavras como orgueilleux ou Monseigneur. ${ }^{17}$ Distante dessas propostas radicais, a prática dos editores e tipógrafos, mesmo conservando algum vínculo com a oralização, limita as inovaçóes à fixação das pausas.

O texto fundamental, nesse sentido, é do impressor (e autor) Etienne Dolet, intitulado La Punctuation de la langue française. ${ }^{18}$ Ele define, em 1540, as novas convenções tipográficas que devem distinguir, conforme a duração da interrupção e a posição na frase, a vírgula, o ponto e vírgula (colocado em sentença suspensa e não terminada) e o ponto final, que "se coloca sempre ao final da sentença”. Tal distribuição da pontuação remete, ao mesmo tempo, às divisóes do discurso e o ritmo da leitura em voz alta. Os dicionários de língua do final do século XVII confirmam a eficácia do sistema proposto por Dolet (enriquecido dos dois pontos intermediários entre o ponto e vírgula e o ponto final), mas também a distância entre a voz leitora e a pontuação, considerada, de acordo com o termo do dicionário de Fueretière, como uma "observação gramatical" que marca as divisóes do discurso. ${ }^{19}$ Em um exemplo de emprego do termo, Furetière indica: "Este Corretor de Imprensa compreende muito bem a pontuação”. Atribui assim à pontuação a competência filológica própria aos corretores que preparam os manuscritos pela impressão.

Então, devemos pensar que os autores nunca controlam a pontuação de seus textos? Talvez não, se recordarmos um outro exemplo de Furetière: "A exatidão deste Autor chega até mesmo a dar atenção aos pontos e vírgulas"?20 É possível encontrar traços dessa "exatidão" dos autores nas edições impressas? Vejamos o caso de Molière. A pontuação das primeiras ediçôes das peças de Molière atesta claramente seu vínculo com a oralidade, para destinar o texto impresso à uma leitura em voz alta ou uma recitação ou para permitir ao leitor a reconstrução dos tempos e das pausas da interpretaçôes dos atores. Nas ediçóes posteriores, a partir do mesmo século XVII, esta primeira pontuação é esquecida e uma pontuação sintática é imposta aos textos.

A passagem não é isenta de efeitos no próprio sentido das obras. As primeiras pontuações, sempre mais numerosas, diferenciam mais fortemente os personagens, indicam pausas

\footnotetext{
${ }^{17}$ RONSARD, Pierre de. "Préface sur la Franciade touchant le poème héroïque". In : . Euvres complètes, Edition établie par Jean Céard, Daniel Ménager et Michel Simonin. Paris: Gallimard, Bibliothèque de la Pléiade, 1993, Tome I, p. 1177-1180.

${ }^{18}$ Cf. DOLET, Etienne. La manière de bien traduire d'une langue en autre. D'avantage de la ponctuation de la langue Françoyse, plus des accents d'ycelle. Lyon: Chez Dolet mesme, 1540 (reproduzido em Nina Catach, Op. cit.).

${ }^{19}$ Cf. "Ponctuation". In : FURETIÈRE, Antoine. Dictionnaire Universel. Haia e Roterdão: Arnout e Reinier Leers, 1690 .

20 "Virgule". In: FURETIÈRE, Antoine. Dictionnaire Universel. Op. cit.
} 
que permitem mais jogos de cena e evidenciam palavras carregadas de significação singular. Enquanto o último verso de Tartufo não comporta nenhuma vírgula nas ediçôes modernas, a edição de 1669 destaca a última palavra da obra, "sincero", graças a uma vírgula final: "E por um doce himeneu, coroar em Valère / A chama de um amante generoso, e sincero". ${ }^{21}$ A palavra "sincero" é assim claramente designada como o antônimo daquela que figura no título: Tartufo, ou o Impostor. Devemos atribuir a Molière essa pontuação que ensina ao leitor como deve dizer (ou ler) os versos e ressaltar algumas palavras, geralmente dotadas de capitais, também suprimidas na ediçôes modernas? Isso seria esquecer a importância das intervençôes dos corretores e tipógrafos sobre os textos. Mas é certo também que as primeiras ediçôes registram alguns elementos das representaçôes e, assim, podem ser consideradas como vestígios das intençôes estéticas do dramaturgo.

A reflexão aqui esboçada levanta vários problemas gerais. O primeiro é a datação da passagem da pontuação retórica à pontuação gramatical. Ela se organizaria de acordo com uma trajetória cronológica única, cujo momento decisivo seria o final do século XVII? Obedeceria a ritmos diferentes conforme os gêneros? Ou então, não se deveria relacionar essas variaçóes às diversas destinaçóes, contemporâneas umas às outras, de uma mesma obra?

Segundo problema: as razóes que sustentam as tentativas de restauração da pontuação de oralização no século XVIII. Benjamin Franklin imaginou diversos dispositivos capazes de manter o papel do orador público em meio a um povo disperso e assim de vincular a força antiga da retórica e da fala viva com a nova definição do espaço público e político, que tem as dimensôes de uma vasta república. Por um lado, os autores do "discursos públicos" são convidados a fazer uso dos gêneros mais diretamente ligados à oralidade: o provérbio, o diálogo, a carta (que pertence ao gênero oratório). Por outro lado, a aprendizagem da leitura em voz alta, que ensina a duraçáo das pausas e o tom da voz, deve se tornar um elemento fundamental do curriculum escolar. Enfim, uma reforma das convençôes das imprensas deve tornar mais fácil a oralizaçáo dos textos graças a uma tipografia que joga com os vários caracteres, que coloca capitais em algumas palavras e que deve adotar em inglês os pontos de exclamação ou de interrogaçáo invertidos, que o espanhol coloca no início da frase. ${ }^{22}$ Assim poderá estar assegurada a reprodução de modo idêntico dos textos impressos nas "performances" oratórias de diferentes oradores. Desso modo, a voz do "publick Orator" poderá ser transmitida como se ele estivesse presente na sua própria ausência.

A construção da significação dos textos depende estritamente das formas que comandam sua transcrição e governam sua transmissão. Contra todas as abordagens críticas que consideram sem importância a materialidade dos textos e as modalidades de sua apropriação, devemos lembrar que identificar os efeitos de sentido produzidos pelas modalidade

${ }^{21}$ Tradução livre a partir de MOLIÈRE, J. B. P. De. Le Tartuffe, ou l'Imposteur. In: Euvres complètes. Edition dirigée par Georges Forestier et Claude Bourqui. Paris: Gallimard, 2010, Bibliothèque de la Pléiade, Tome II, p. 190.

${ }^{22}$ FRANKLIN, Benjamin. Letter to Noab Webster, Jr., 26 de Dezembro de 1789. In: franklinpapers.org. 
de inscrição dos textos, sobre as páginas do livros ou nas "performances" das vozes, é uma necessidade para compreender, em sua historicidade e em suas diferenças, os usos interpretativos dos discursos.

É o que mostra o capítulo escrito por Andrea Daher no livro Oral por escrito que estuda as mutações das modalidades de transcrição da oralidade indígena e da palavra selvagem entre as ediçôes franceses antigas e as traduçóes modernas em português das obras de Jean de Léry ou de Claude d'Abbeville, publicadas no Brasil, tendo por tradutores Tristão de Alencar Araripe, Monteiro Lobato, Sérgio Milliet e Cézar Augusto Marques. Apresenta assim sua pesquisa: "Procuro contrastar os usos e funções das representaçôes do índio tupinambá dotado de capacidade enunciativa, em duas circunstâncias históricas específicas: por um lado, no presente da publicação dos relatos de Jean de Léry e de Claude d'Abbeville, nos séculos XVI e XVII; e, por outro, nos séculos XIX e XX, nas traduçôes brasileiras dessas narrativas, que veiculam essas representaçôes em nova forma material, tanto linguística quanto editorial, esvaziando ou anulando os efeitos antes produzidos, nas edições originais". ${ }^{23}$

Não posso imaginar melhor ilustração das tensôes sempre presentes entre a perda irremediável da oralidade e todos os dispositivos escritos que permitem seu resgate.

Roger Chartier

\section{Referências}

BOURDIEU, Pierre. O senso prático. Petrópolis: Editora Vozes, 2009.

BOUZA, Fernando. Corre manuscrito. Una historia cultural del Siglo de Oro. Madrid: Marcial Pons, 2001.

. Palabra e imagen en la Corte. Cultura oral y visual de la nobleza en el Siglo de Oro. Madri: Abada Editores, 2003.

CATACH, Nina. L'Orthographie française à l'époque de la Renaissance (auteurs, imprimeurs, ateliers d'imprimerie). Genebra: Librairie Droz, 1968.

CERVANTES, Miguel de. O engenhoso fidalgo D. Quixote de la Mancha. Tradução de Sérgio Molina. São Paulo: Editora 34, 2010.

CHARTIER, Roger. "Pausas e tônicas". In: . A mão do autor e a mente do editor. Tradução George Schlesinger. São Paulo: Editora Unesp, 2013, p. 153-173.

DAHER, Andrea. A oralidade perdida. Ensaios de história das práticas letradas. Rio de Janeiro: Civilização Brasileira, 2012, p. 96.

${ }^{23}$ DAHER, Andrea. Oral por escrito. Op. cit., p. 16. e p. 137-190. 
(Org.). Oral por escrito. A oralidade na ordem da escrita, da retórica à literatura. Chapecó; Argos; Florianópolis: Editora UFSC, 2018.

DOLET, Etienne. La manière de bien traduire d'une langue en autre. D'avantage de la ponctuation de la langue Françoyse, plus des accents d'ycelle. Lyon: Chez Dolet mesme, 1540 (reproduzido en Nina Catach, Op. cit.).

DU FAIL, Noël. Propos rustiques de Maistre Leon Ladulfi Champenois. In: Conteurs français du XVIe siècle. Textes présentés et annotés par Pierre Jourda, Gallimard, Bibliothèque de la Pléiade, 1965 [1548], pp. 620-621.

FRANKLIN, Benjamin. Letter to Noah Webster, Jr., 26 de Dezembro de 1789. In: franklinpapers.org.

FRENK, Margit. Entre la voz y el silencio. La lectura en tiempos de Cervantes. México: Fondo de Cultura Económica, 2005.

FURETIÈRE, Antoine. Dictionnaire Universel. Haia e Roterdão: Arnout e Reinier Leers, 1690.

GOODY, Jack. A domesticação da mente selvagem. Petrópolis: Editora Vozes, 2012.

GRAFTON, Anthony. The Culture of Correction in Renaissance Europe. Londres: British Library, 2011.

McKENZIE, D.F. "Speech - Manuscript - Print". In: Making Meaning: "Printers of the Mind" and other Essays. Edited by Peter D. McDonald and Michael F. Suarez, S.J. Amherst: University of Massachussetts Press, 2002.

MOLIÈRE, J. B. P. De. Le Tartuffe, ou l'Imposteur. In: Molière, Cuures complètes. Edition dirigée par Georges Forestier et Claude Bourqui. Paris: Gallimard, 2010, Bibliothèque de la Pléiade, Tome II, p. 190.

NELSON, William. "From 'Listen, Lording' to 'Dear Reader'", University of Toronto Quarterly. A Canadian Journal of the Humanities, Vol. XLVI, n² 2, 1976-1977, p. 110-124. RONSARD, Pierre de. "Préface sur la Franciade touchant le poème hérö̈que". In :

Euvres complètes, Edition établie par Jean Céard, Daniel Ménager et Michel Simonin. Paris: Gallimard, Bibliothèque de la Pléiade, 1993, Tome I, p. 1177-1180.

ZUMTHOR, Paul. A letra e a voz. A "literatura" medieval. São Paulo: Companhia das Letras, 1993. 
Na primeira vez em que li A Oralidade perdida, por indicação do meu colega Joáo Adolfo Hansen e com o objetivo de preparar um curso de graduação sobre as chamadas Letras coloniais, fiquei absolutamente fascinado.

Embora haja ali muita erudição, o livro não faz praça disso. Embora seja muito rigoroso, não há nele nenhum apreço pelas categorias difíceis. Embora haja muita convicção e certeza do que está sendo dito, como se as letras impressas viessem um pouco calcadas na página, não há ali nenhuma categorização peremptória ou intenção prescritiva.

O que mais me fascinou no livro foi justamente isto: a abertura que ele oferece e a liberdade que ele inspira para pensar em tantos outros assuntos. Além de farta matéria para o curso sobre escritos do periodo colonial, encontrei nele novas possibilidades de pensar questóes de outros tempos e espaços.

Saí já da primeira leitura com a sensação de que A oralidade perdida tinha muito a dizer sobre Machado de Assis, e muito especialmente sobre um livro em geral considerado corpo estranho na obra machadiana, Americanas.

Americanas é um volume composto de 13 poemas e publicado em 1875, frequentemente referido como o livro de poemas indianistas de Machado de Assis, amplamente entendido como obra extemporânea e dissonante. É como se Machado, em 1875, recuasse em relação ao que escrevera dois anos antes sobre os limites do nacionalismo-indianista romântico, num ensaio seu muito conhecido e citado, "Notícia da atual literatura brasileira - Instinto de Nacionalidade".

Nos últimos anos, venho buscando fazer uma leitura mais integrada e integradora da obra de Machado de Assis. Procuro levar adiante uma proposição do Silviano Santiago, feita há 50 anos mas ainda longe de ser executada, de se ler a obra de Machado de Assis como um todo coerentemente organizado.

Todos sabemos que Machado vem sendo estudado a partir da noção de ruptura, seja em relação ao que veio antes dele, seja pela ênfase na cisão entre as chamadas primeira e segunda fases, entre o Machado romântico e o realista, o Machadinho e o verdadeiro Machado etc. Ou mesmo pela divisão da sua obra em gêneros estanques, com valorização de alguns romances pós-Brás Cubas e de uma fração pequena dos seus contos.

Isso resultou no descarte de grande parte dos seus escritos, especialmente da sua poesia $\mathrm{e}$ do seu teatro, considerados menores e desconectados da grande obra. Americanas é um desses escritos difíceis de se encaixar no conjunto da obra, ou pelo menos do que se consagrou como obra machadiana. 
E me parece que $A$ Oralidade perdida ${ }^{24}$ ajuda a pensar esse livro e situá-lo melhor no contexto da sua obra.

Dou continuidade aqui ao que escrevi no livro organizado por Andrea Daher, Oral por escrito, ${ }^{25}$ apresentando algumas consideraçôes a respeito de Americanas e do posicionamento de Machado em relação à figuração do indígena (e, por extensão, a questóes relativas à oralidade e à escrita). Retomo, para isso, três ou quatro proposiçôes fortes feitas por ela em A Oralidade perdida para examinar de que maneira são tratadas por Machado de Assis em Americanas.

1. A primeira dessas proposiçôes refere-se a Montaigne em "Dos canibais". Esse é o ponto de partida do seu livro, que começa retomando o ensaio "Dos canibais", chamando a atençáo para o fato de que, no encontro de Montaigne com os Tupinambá, três coisas são ditas. As duas primeiras são traduzidas pelo intérprete, e a terceira coisa dita pelos Tupinambá não é ouvida nem traduzida. E é justamente o silenciamento dessa terceira coisa que permitiria a Montaigne escrever um discurso sobre aqueles homens sem calças.

Machado conclui a "Advertência" de Americanas com a mesma frase famosa com que Montaigne encerra o seu ensaio "Dos canibais" ("mas, ora, eles não usam calças"), sugerindo haver na frase de Montaigne uma pontazinha de maliciosa ingenuidade.

Na referência a Montaigne, certamente há por parte de Machado muito mais malícia e ironia do que ingenuidade. A afirmação de que os índios não usam calças, na "Advertência" de um livro intitulado Americanas, parece marcar uma diferença tão profunda e inconciliável quanto superficial e, no fundo, irrelevante entre quem escreve e aqueles que são representados pela escrita - os indígenas.

Com sua provocação nada ingênua, Machado sugere que somente a partir da assunção da falta, ou da abstração dos acessórios ausentes condensados no vocábulo "calça", (e veremos adiante o modo provocativo como ele se refere aos acessórios indígenas), será possível enxergar os traços que permitam tomar os indígenas de maneira menos mistificadora e como matéria ficcional não exótica.

Tanto em Montaigne como em Machado a palavra indígena aparece silenciada na "economia escriturária", expressão de Michel de Certeau lembrada em $A$ oralidade perdida, referindo-se a "um novo modo de produção, de transformação e de estocagem da língua" que emerge no momento mesmo em que se estabelecem os primeiros contatos dos europeus com as populaçōes ameríndias.

Em Americanas, Machado utiliza vários recursos que enfatizam essa economia escriturária no trato dos indígenas. Já nos versos iniciais do poema que abre o livro, a transmissáo do nome da moça índia que dá título ao poema, Potira, é assim descrita:

\footnotetext{
${ }^{24}$ Cf. DAHER, Andrea. A oralidade perdida. Op. cit.

${ }^{25}$ Cf. DAHER, Andrea (Org.). Oral por escrito. Op. cit. 
Moça cristã das solidóes antigas,

Em que áurea folha reviveu teu nome?

Nem o eco das matas seculares,

Nem a voz das sonoras cachoeiras,

O transmitiu aos séculos futuros.

O sentido a princípio bivalente de folha - elemento da natureza e também produto humano - no correr do poema tende para a segunda acepção, pois os versos seguintes contam que não foram os elementos da natureza - nem as matas seculares nem a voz das sonoras cachoeiras - que deram curso ao nome e à história de Potira, mas sim as áureas folhas, de papel e tinta. A história de Potira, portanto, não emana nem se transmite pela natureza, mas pelos livros. De fato, antes de chegar aos versos iniciais passamos não por uma, mas por duas epígrafes.

A primeira é extraída de um trecho do padre Simão de Vasconcelos, da Companhia de Jesus, que conta a história da índia cristã e casada com um homem branco, raptada pelos tamoios e cruelmente morta quando se nega a se entregar ao chefe da tribo. História semelhante, sabemos em nota, é contada pelo padre Anchieta. A segunda epígrafe é composta com dois versos de Orlando Furioso, referência que no poema sustenta a caracterização da indígena como "cristã Lucrécia”, a Lucrécia Bórgia a quem o poema de Ariosto é dedicado.

As referências não param por aí. $\mathrm{O}$ poema de Machado também dialoga em surdina com Iracema, de Alencar, produzindo um giro notável. Não há aqui brisa nem jandaia a propagar o nome da infeliz indígena. $\mathrm{E}$ ainda que as duas mulheres convertidas à religião cristã do esposo tenham destino idêntico - a morte precoce -, a índia de Machado sacrifica-se em nome do marido ausente, sem deixar descendência ou fundar nação, ao contrário de Iracema, que nos lega Moacir e, por extensão, os brasileiros.

Potira compóe-se assim a partir de um feixe de textos - dos jesuítas, de Ariosto e de Alencar -, e ao final sobrevive apenas no silêncio do poema impresso.

A emolduração do silêncio indígena pela escrita é central também em "Última jornada", penúltimo poema de Americanas.

Nele, o poeta trata do amor entre indígenas de tribos inimigas que conhecem um fim trágico. E o poema se desenvolve justamente no momento em que ambos são lançados pelos ares, em sua última jornada.

Para sua composição, Machado parte de epígrafe também retirada de Montaigne, adota procedimentos consagrados na poesia portuguesa, o que equivale dizer na poesia não-indígena, e empresta de Dante Alighieri o corte estrófico e o tema clássico do amor entre Paolo e Francesca.

As soluçóes adotadas nesse poema, muitas décadas mais tarde chamaram a atenção de Mário de Andrade pelo que haveria nelas de, palavras de Mário, "ilógico" e "não natural”: 
[...] a imagem principal do poema é a mesma nas duas poesias ["Última jornada" e o Canto $\mathrm{V}$ do Inferno, de Dante]: os dois corpos de casais amantes e desgraçados voando pelos ares. Além disso, o fato de Machado de Assis, em vez de se prender a qualquer concepçáo mais logicamente ameríndia, fazer dos seus mortos recentes, seres sempre dotados de corpo e espírito e adotar a divisão cristã de céu e inferno, obedece exatamente à concepção dantesca. ${ }^{26}$

A crítica de Mário de Andrade vai no mesmo sentido do que disseram os críticos contemporâneos de Machado, que apontaram nos poemas de Americanas justamente a falta do traço local, americano. Mário vai além, ao expressar sua surpresa com o modo como Machado expóe a lacuna da fala indígena:

[...] ainda há que lembrar a invenção genial de Dante, a que Machado corresponde. Em Dante só um dos amados fala; toda a descrição do caso é feita por Francesa. Em Machado só o guerreiro fala. Nos dois pares o outro ser conserva um silêncio de esplêndida e terrível expressividade. Há um ilogismo em relação ao teatral, à dialogação, à vida, que em ambos os casos, mas talvez mesmo ainda mais em Machado de Assis que em Dante, é da maior força poética. ${ }^{27}$

Fica claro o incômodo de Mário com a opção pelo poético em detrimento da vida, pelo monólogo em vez do diálogo, oposiçóes que se poderiam traduzir numa escolha pelo efeito da escrita em detrimento do recurso a uma certa naturalidade e espontaneidade do oral, mas por outro lado Mário nota a questão crucial: a audácia de Machado de fazer a indígena falar pela ausência da sua voz, pelo silêncio.Veja-se que a expressividade do silêncio, notada por Mário nesse poema, e a meu ver generalizada em Americanas, será uma das forças da prosa machadiana. Esse é um recurso central, por exemplo, em contos e romances nos quais personagens femininas, silenciadas pela fala masculina, falam através do silêncio. Ele está presente num conto quase contemporâneo a Americanas, "O relógio de ouro", e, claro, no caso mais conhecido de Dom Casmurro, em que parte da força extraordinária de Capitu e da sua onipresença no romance - bem como na recepção do romance - deriva paradoxalmente do seu silenciamento.

Para não deixar dúvida do aparato escrito mobilizado para a construção dos seus poemas e do silêncio dos seus indígenas, Machado explicita o artifício com a proliferação de recursos paratextuais, antepondo a muitos poemas não uma, mas duas epígrafes - como vimos em "Potira" - e acrescentando-lhe notas. Internamente, nos poemas, adota esquemas métricos e rímicos que enfatizam o artifício poético, como o uso de versos alexandrinos e decassílabos, que fazem maioria em Americanas. Além disso, desnaturaliza os vínculos exclusivos entre as

\footnotetext{
${ }^{26}$ ANDRADE, Mário de. "Machado de Assis (1939)”. In: Aspectos da literatura brasileira. Belo Horizonte: Itatiaia, 2002, p. 119. Grifos meus.

${ }^{27}$ Idem.
} 
histórias indígenas e a literatura local, fazendo conviver num mesmo poema, como já vimos, referências aos jesuítas e a Montaigne, Alencar e Ariosto, Gonçalves Dias e Dante.

Com isso, Machado enfatizava a mediação de outras fontes literárias na construção dos seus poemas de motivo indianista, inserindo-os desde o início em constelaçôes textuais. É como se lembrasse que os "nossos aborígenes" estão sendo reduzidos, diante dos olhos do leitor de Americanas, aos silêncios do texto escrito. A operaçáo (e aqui não importa se intencional ou não por parte de Machado) remete aos empreendimentos coloniais de redução das línguas selvagens à gramática latina e, posteriormente, às línguas dos colonizadores. A diferença é que a redução agora se dá em segundo ou terceiro grau, por meio da composição do índio por meio da citação, ou da citação da citação, de textos escritos, explicitando o processo principal de representação - e sujeição, pela escrita - dos indígenas em mais de três séculos de colonização. A dimensão histórica do processo, reclamada pelos primeiros leitores de Americanas, aparece assim de maneira contundente, incidindo na estrutura mesma de organização do livro e na forma dos poemas, e não por meio da recomposição de fatos e situaçôes verificáveis em relatos históricos ou etnográficos ou pela busca de efeitos de realidade.

2. A segunda proposição de A Oralidade perdida de que lanço mão para pensar Americanas de Machado de Assis diz respeito à tensão entre índio histórico e índio contemporâneo.

Ao investir na exposição do processo de construção escrita dos indígenas, convocando os construtores de índios mais engenhosos da poesia e da prosa modernas e contemporâneas, Machado reconhece, e passa ao largo do que Andrea Daher qualifica como "tensão onipresente nas Letras brasileiras": "entre a figura do 'índio histórico', passível de se conhecer através das descriçôes - imperfeitas, porém - de relatos 'antigos', e o 'índio contemporâneo', passível de ser visto, embora ameaçado pela destruição a que fora submetido”. ${ }^{28}$

Ao contrário de Alencar, que busca no uso do vocabulário tupi e nas referências históricas a autorização para o uso literário, Machado explicita, valoriza e considera suficiente o uso literário tanto do vocabulário tupi quanto dos textos de cronistas e historiadores.

Ao empregar palavras tais como "cauim", "pocema", "muçurana", "tangapema" e "kanitar", abre uma nota para afirmar ser "ocioso explicar em notas o sentido" dessas palavras, "com as quais todo o leitor brasileiro está já familiarizado, graças ao uso que delas têm feito poetas e prosadores". ${ }^{29}$

As ocorrências anteriores em outros textos literários parecem-lhe suficientes para legitimar literariamente o uso dos termos. Em vez de recorrer à autoridade histórica e etnográfica, Machado expóe o indígena (e a oralidade) como invençóes literárias.

Assim, a propósito do uso que faz do termo Tupã, que o Dr. Couto de Magalhães dissera nunca ter encontrado nas tribos que frequentou, Machado justifica:

\footnotetext{
${ }^{28}$ DAHER, Andrea. A oralidade perdida. Op. cit., p. 33.

${ }^{29}$ Ibidem, p. 199.
} 
Sem embargo das razóes alegadas pelo Sr. Dr. Magalhães, que todas são de incontestável procedência, conservei Tupá nos versos que ora dou a lume; fi-lo por ir com as tradiçóes literárias que achei, tradiçóes que nada valem no terreno da investigação científica, mas que têm por si o serem aceitas e haverem adquirido um como direito de cidade. ${ }^{30}$

Como quem não quer nada, Machado abala a autoridade do general Couto de Magalhães, que propunha civilizar o indígena ensinando-lhe o português. Couto de Magalhães, como mostra Andrea Daher, é um dos mentores da concepção do selvagem como outro e como diferença cultural, a ser submetido ao enquadramento político-militar da monarquia por meio da conversáo linguística.

Passando ao largo desse índio romântico, pensado como outro e como diferença cultural (e até mesmo da concepção jesuítica do índio como mesmo ou próximo), Machado toma o índio à distância, como partícipe dos problemas fundamentais e comuns a todos os homens.

Daí afirmar já na "Advertência" à primeira edição de Americanas:

A generosidade, a constância, o valor, a piedade hăo de ser sempre elementos de arte, ou brilhem nas margens do Scamandro ou nas do Tocantins. O exterior muda; o capacete de Ajax é mais clássico e polido que o kanitar de Itajuba; a sandália de Calypso é um primor de arte que não achamos na planta nua de Lindoia. Esta é, porém, a parte inferior da poesia, a parte acessória. O essencial é a alma do homem. ${ }^{31}$

Explicita-se aí a recusa à exotizaçáo do indígena por meio do que chama de acessórios cujo corolário é a falta de calças.

O mesmo movimento de des-exotização se nota na organização do livro, conforme explicitado também nas primeiras linhas da "Advertência":

O título de Americanas explica a natureza dos objetos tratados neste livro, do qual excluí o que podia destoar daquela denominação comum. Não se deve entender que tudo o que aqui vai seja relativo aos nossos aborígenes. Ao lado de "Potira" e "Niâni", por exemplo, quadros da vida selvagem, há "Cristã Nova" e "Sabina", cuja ação é passada no centro da civilização. ${ }^{32}$

Assim, as mulheres indígenas de Machado vivem dramas parecidos aos de Ângela, a cristã nova presumivelmente do século XVII, "alma infeliz [que] nem toda era Cristo/ Nem toda Moisés"; aos da mucama do poema "Sabina", cativa e mestiça que se apaixona e engravida do filho do seu senhor, para ao final ser preterida, junto com o filho, pela "don-

\footnotetext{
${ }^{30}$ MACHADO DE ASSIS. Americanas. Rio de Janeiro: Garnier, 1875, p. 198. Grifo meu.

${ }^{31}$ Ibidem, p. VI.

${ }^{32}$ Ibidem, p. V.
} 
zela gentil" que o rapaz volúvel conheceu na corte; e também aos das mulheres burguesas do século XIX.

O que é dito na "Advertência" aparece sintetizado nos versos singelos de "Niâni", história do amor infeliz da índia guaicuru, "tão triste como os que contam / Pelas terras de além-mar", e que terminam assim: "Que assim se morre de amores/ Aonde habita o jaguar, / Como as princesas morriam / Pelas terras de além-mar".

A esta altura, nos perguntamos quanto temos aí de adesáo do escritor ao processo de projeção sobre os índios de critérios universais, definidores da "humanidade", ${ }^{33}$ e quanto há de exposiçáo e potencial denúncia desse mesmo processo. É mesmo difícil precisar as fronteiras entre ingenuidade e malícia (a combinação mencionada na "Advertência" a propósito de Montaigne), o que nos dá certeza de que de fato estamos aqui em águas machadianas.

3. Por fim, gostaria de chamar a atenção para o modo como Machado lida, em Americanas, com outra referência fundamental para a figuraçáo do índio romântico, estudada por Andrea Daher: Ferdinand Denis. Se coube a Denis anunciar o índio como "objeto, por excelência, das Letras abrasileiradas", ${ }^{34}$ com todas as consequências que isso teve para a produção literária do século XIX, é interessante notar que, até onde se sabe, a única menção de Machado a Denis, em toda sua obra, se faz numa nota de Americanas, justamente a propósito do poema "Os semeadores", elogio e defesa da empresa jesuítica.

O trecho de Le Brésil, de Denis, que Machado cita em francês, diz o seguinte na tradução para o português:

Haveria grande injustiça em julgar os jesuítas do século XVI e seus trabalhos pelas ideias que pode inspirar o sistema seguido nas missões. Ali é possível ver projetos ambiciosos se aliarem a visóes hábeis; nos primeiros trabalhos executados pelos padres da Companhia, no Brasil, tudo foi desinteressado; e, se necessário, a narração de suas fadigas e padecimentos poderia prová-lo. ${ }^{35}$

A perspectiva adotada pelo poema, de defesa dos "Paulos do Sertão", pode não ser a mais simpática e também pode causar desconcerto. Mas ela também expõe sem mistificação, para quem quiser assim ler, tanto a posição de Denis em relação à empresa colonial jesuítica quanto a tensão onipresente entre colonizadores e indígenas, escrita e oralidade, central em todo o processo de colonização.

É magnífico o modo como Andrea Daher recompõe a figura de Ferdinand Denis em A Oralidade perdida: o patrono e benemérito da literatura brasileira é apresentado, de certo modo, "de calças curtas", como alguém que veio ao Brasil por motivaçóes financeiras, obtendo vantagens pecuniárias pelo "envio à França de exemplares de aves empalhadas, especial-

\footnotetext{
${ }^{33}$ DAHER, Andrea. A oralidade perdida. Op. cit., p. 51.

${ }^{34}$ Ibidem, p. 188.

${ }^{35}$ MACHADO DE ASSIS. Americanas. Op. cit., p. 193.
} 
mente colibris, e minerais a serem vendidos”, conectando à atividade intelectual ao comércio de bens exóticos e inscrevendo sua produção bibliográfica no mesmo gabinete de curiosidades que comportava arcos e flechas, pedras e madeiras, pássaros empalhados. Segundo ela,

[...] a relação de Ferdinand Denis com as Letras brasileiras é oriunda, nos seus primórdios, da mesma lógica do mercado europeu de bens exóticos que motivou sua vinda para o Brasil e lhe garantiu a sobrevivência durante quatro anos. $\mathrm{O}$ mercado oitocentista europeu de bens exóticos caracterizava-se, justamente, pela diversidade de seus produtos: assim como os livros, seria preciso incluir, por exemplo, nessa economia, outros objetos como a fotografia, massivamente presente em anúncios publicitários, cartóes de visita, cartóes postais, álbuns e outros suportes de larga circulação no Brasil e na Europa, no final do século XIX e começo do XX. Objetos como esses não são considerados, historicamente, como integrantes do mercado de bens exóticos oitocentista por conta do mesmo anacronismo romântico que os concebe como bens artísticos quase autônomos, abstraídos, portanto, das formas de circulação e de uso que tinham no seu tempo. ${ }^{36}$

Foi o traço pitoresco do modelo consagrado por Denis, ou a partir de Denis, de busca de singularidade da poesia nas cenas da natureza - sugerido pelo título de sua obra, Cenas da natureza sob os trópicos e sua influência na poesia - que foi constantemente solapado por Machado em Americanas. Como aliás será no conjunto da obra de Machado de Assis, que por tanto tempo foi percebida como obra em que faltavam as cenas da natureza, a paisagem brasileira.

Desde os primeiros versos de Americanas, estamos diante de uma natureza indiferente ao destino humano, indiferença que ganhará ares de crueldade com a Pandora do delírio de Brás Cubas.

Muitos anos mais tarde, em crônica da série "A Semana" publicada em 1893, Machado inverte de modo exemplar o "protocolo do olhar" que Andrea Daher atribui a Denis. Ao levar um viajante para conhecer o Rio de Janeiro, o cronista começa a lhe falar da cidade e da sua história. $\mathrm{O}$ viajante se mostra interessado em conhecer alguma velha construção.

Ajustamos que no dia seguinte iria buscá-lo para subir o morro do Castelo. Era uma bela manhã, não sei se de inverno ou primavera. Subimos; eu, para dispor-lhe o espírito, ialhe pintando o tempo que por aquela mesma ladeira passavam os padres jesuítas, a cidade pequena, os costumes toscos, a devoção grande e sincera. Chegamos ao alto, a igreja estava aberta e entramos. Sei que não são ruínas de Atenas; mas cada um mostra o que possui. $\mathrm{O}$ viajante entrou, deu uma volta, saiu e foi postar-se junto à muralha, fitando o mar, o céu e as montanhas, e, ao cabo de cinco minutos: "Que natureza que vocês têm!

${ }^{36}$ DAHER, Andrea. A oralidade perdida. Op. cit., p. 192. 
Ao que o cronista comenta, desolado: "A admiração do nosso hóspede excluía qualquer ideia da ação humana. Não me perguntou pela fundação das fortalezas, nem pelos nomes dos navios que estavam ancorados. Foi só a natureza.”

Machado evita o quanto pode o olhar exotizante e monumentalizante, que busca nas cenas da natureza a singularidade do Brasil e da poesia brasileira. Se Denis propóe que, nos trópicos, "uma palmeira que se eleva no meio da solidão substitui a coluna destinada a perpetuar entre nós [europeus] um fato glorioso", Machado, em verso e prosa, inverte esse "protocolo do olhar", chamando a atenção constantemente para as construçóes, ainda que acanhadas e ruinosas.

É aliás notável a recorrência do termo "ruína" e derivações, nos poemas de Americanas. Os versos finais da "Cantiga do rosto branco" sintetizam o tom ruinoso que marca todas as relaçóes entre as personagens dos poemas - e de boa parte da prosa machadiana:

Quem ali passa, contemplando os restos

Da cabana, que a erva toda esconde,

Que ruínas são essas interroga

E ninguém lhe responde. ${ }^{37}$

Essa imagem da casa arruinada retorna no romance Helena, e de maneira magnífica em Esaú e Jacó, numa cena em que Flora mostra ao conselheiro Aires os desenhos que fez: "Flora mostrou-lhe os desenhos que fizera, paisagens, figuras, um pedaço da estrada da Tijuca, um chafariz antigo, um Princípio de casa. Era uma dessas casas, que alguém começou muitos anos antes, e ninguém acabou, ficando só duas ou três paredes, ruína sem história." ${ }^{38}$

A leitura de Americanas a partir de A Oralidade perdida nos mostra que Machado, no seu livro, abala as principais colunas que sustentam o complexo artístico-ideológico do romantismo brasileiro. Penso que o livro da Andrea Daher oferece elementos para retirar Americanas da sua suposta extemporaneidade, permitindo reintegrá-lo no conjunto da obra machadiana. Muitos dos procedimentos adotados aqui - a ênfase no artifício, a proliferação e a variedade das referências literárias, a expressão pelo silêncio, o deslocamento do interesse da natureza para os dramas íntimos das personagens, algumas imagens - serão definidores do que entendemos hoje como a grande obra de Machado de Assis.

Lido através das chaves oferecidas em $A$ Oralidade perdida, nos deparamos mais uma vez com o assombroso potencial desmonumentalizante da sua escrita, o que se dá, a meu ver, pela exposiçáo sistemática e minuciosa dos processos de monumentalização. (Não deixa de ser curioso e irônico que esse mesmo escritor tenha investido tanto na construçáo de monumentos literários - a Academia Brasileira de Letras é a ação mais importante nesse sentido -

\footnotetext{
${ }^{37}$ MACHADO DE ASSIS. Americanas. Op. cit., p. 140.

${ }^{38}$ MACHADO DE ASSIS. Esaú e Jacob. Rio de Janeiro: H. Garnier, 1904, p. 303. Grifos no original.
} 
e seja recorrentemente transformado em monumento, a despeito do caráter profundamente dissolvente da sua escrita.)

Ao passar em revista todos os principais modos de figuração dos indígenas em quatro séculos - de Montaigne aos cronistas e jesuítas, de Ferdinand Denis ao general Couto de Magalhães, de Gonçalves Dias a José de Alencar —, Machado não só realiza a liquidação do nacionalismo-indianista romântico, mas o faz com profundo conhecimento de causa, e com método.

Hélio de Seixas Guimarães

\section{Referências}

ANDRADE, Mário de. "Machado de Assis (1939)". In: Aspectos da literatura brasileira. Belo Horizonte: Itatiaia, 2002.

DAHER, Andrea. A oralidade perdida. Ensaios de história das práticas letradas. Rio de Janeiro: Civilizaçẫo Brasileira, 2012.

(Org.). Oral por escrito. A oralidade na ordem da escrita, da retórica à literatura. Chapecó; Argos; Florianópolis: Editora UFSC, 2018.

MACHADO DE ASSIS. Americanas. Rio de Janeiro: Garnier, 1875.

. Esaú e Jacob. Rio de Janeiro: H. Garnier, 1904. 
Conheço Andrea Daher há bastantes anos e tenho acompanhado de perto seu trabalho, ora na forma de livros, em que se discute a complexa relação entre oralidade e operação escriturária nas monarquias do Ocidente europeu, nos séculos XVI e XVII, ora na forma de Jornadas, como a Jornada de Estudos Sobre Tradução, que organizou em 10 de agosto de 2017 na UFRJ, quando se tratou de um problema mais geral de tradução de conceitos e categorias, na base do que se pode chamar de "transporte" entre uma "lingua de saida" e uma de linguas de chegada. Assumindo o ponto de vista histórico e sociológico da prática tradutora, o problema então levantado por Andrea Daher girava em torno da velha tópica fidelidade versus traição. E a tarefa do historiador das práticas letradas, como afirmava, consiste, justamente, em dar conta dos efeitos de sentido equivocos produzidos pela traição.

Andrea Daher escreveu dois grandes livros sobre a prática tradutora, mas que extrapolam de longe as muitas e difíceis implicaçôes de toda operaçâo tradutória nos séculos XVI e XVII; reconheceu, nas práticas de composição de discursos em tupi nas obras dos padres capuchinhos franceses do século XVII, procedimentos retóricos e poéticos de produção das falas indias, em que a prosopopeia ou sermonição representa uma suposta voz selvagem em sua liberdade, exterior, aparentemente, a toda captura e aculturação, quando, na verdade, o epos dessa voz já evidencia a parasitação dela por um conjunto de práticas escriturárias que a domesticam e a figuram "selvagem e livre" como efeito de sentido produzido pela apropriação e domesticação: a prosopopeia faz falar um ausente cuja presença é pura mimese em que se conjugam prosopografia e etopeia. Andrea Daher é uma das primeiras entre nós que penetrou nas malhas cerradas dos discursos europeus sobre o Novo Mundo e qual Penélope soube desenovelá-los, a eles, que, independentemente das linguas em que estejam compostos - tupi, francês, português -, são sempre embaraçadíssimos, como dizia o jesuita Antônio Vieira, e que urge desfiar para urdi-los novamente em novos tecidos de significação, o que ela demonstrou ser possivel.

A obra de Andrea Daher tem dois grandes momentos que é preciso referir: o primeiro é sem sombra de dúvida o livro $O$ Brasil francếs ${ }^{39}$, e, o segundo, o livro $A$ Oralidade perdida ${ }^{40}$, cujo subtítulo explica os ensaios aí reunidos e em larga medida a pesquisa que Andrea Daher desenvolveu por anos, tornando-se um dos grandes pesquisadores brasileiros que se dedicaram ao estudo das letras das Monarquias Ibéricas e daquelas, em menor medida, da Itália e França, entre nós: "Ensaios de história das práticas letradas".

\footnotetext{
${ }^{39}$ Cf. DAHER, Andrea. O Brasil francês. As singularidades da França Equinocial, 1612-1615. Rio de Janeiro: Civilização Brasileira, 2007.

${ }^{40}$ Cf. DAHER, Andrea. A oralidade perdida. Op. cit.
} 
Os dois livros de Andrea Daher que referimos empreendem uma ampla e profícua discussão sobre escrita e oralidade e visam a demonstrar como, nos escritos produzidos por europeus no Novo Mundo, vê-se em atividade a maquinaria escritora, mesmo e talvez, sobretudo, quando a fala, a representação da lexis dos caracteres, inscrita na forma de discursos e/ou diálogos, é a dos índios: como nos diz Andrea Daher, quer-se entender justamente o conjunto de dispositivos discursivos então mobilizados para realizar em linhas escritas uma oralidade perdida, cujos sons parecem no entanto ecoar no "costume selvagem", fruto e efeito de um ato de inscrição. A oralidade do costume selvagem dos índios é posta ao mesmo tempo diante dos nossos olhos, porque escrita, e diante dos ouvidos, porque se nos apresenta como um suposto ato de fala dos homens do Novo Mundo. Poder-se-ia dizer que esse falar dos índios, incrustrado em escritos franceses, serviria, como no caso de Jean de Léry, estudado por Michel de Certeau ${ }^{41}$, por Frank Lestringant ${ }^{42}$ e por Andrea Daher ${ }^{43}$, para tornar evidente a operação de dotação de sentido e de consequente utilidade que o europeu, como intérprete, lhe atribui ao constitui-lo. No caso dos padres capuchinhos Claude d'Abbeville ${ }^{44}$ e Yves d'Evreux ${ }^{45}$, o tupi comparece nas narrativas dos missionários na forma de colóquios e discursos miméticos, sem a mediação de voz interposta, produzindo-se assim a figura de um tupinambá dotado de fala e capaz de expressar em sua língua seu desejo de conversão e de aliança com os franceses.

Nas retóricas francesas de meados do século XVI, como a de Antoine Fouquelin, publicada a primeira vez em 1555, é comum haver uma seção dedicada à elocução, dividida comumente em duas grandes subseçôes, uma dedicada aos tropos e outra às figuras: dentre estas últimas encontra-se a prosopopeia, em que nos deteremos por uns instantes. Antoine Fouquelin ensina-nos que a prosopopeia é também chamada sermocinação, palavra por que é normalmente conhecida entre retores portugueses e espanhóis; ela é uma figura de sentença, por meio da qual, nós, "com nossa voz e ação, produzimos uma contrafação e representamos a voz e a personalidade de alguém (voix et personnage d'autrui). O procedimento de que nos fala Antoine Fouquelin é aquele de que trata Aristóteles nas seçôes 7, 8 e 9 de sua Poética ${ }^{46}$, quando, ao discorrer sobre a imitação, assevera que o poeta pode valer-se de sua própria voz ou pode dar passo à voz dos caracteres agentes, pondo de lado a si e deixando outros falarem. Contrariamente ao drama, em que o procedimento mimético impera, em que há somente caracteres agentes (drontes) em interação e em perpétuo dialo-

\footnotetext{
${ }^{41}$ Cf. CERTEAU, Michel de. A escrita da história. São Paulo: Forense Universitária, 2015.

${ }^{42}$ Cf. LESTRINGANT, Frank. O canibal: grandeza e decadência. Brasília: Editora UnB, 1987.

${ }^{43}$ Cf. DAHER, Andrea. O Brasil francês. Op. cit.

${ }^{44}$ Cf. CLAUDE D'ABBEVILLE. Histoire de la mission des peres capucins en l'isle de Maragnan et terres circonuoisines [...]. Paris: François Huby, 1614.

${ }^{45}$ Cf. YVES D’ÉVREUX. Voyage dans le Nord du Brésil fait durant les années 1613 et 1614 [...]. Avec une introduction et notes par M. Ferdinand Denis. Leipzig et Paris: Librairie A. Franck, 1864.

${ }^{46}$ Cf. ARISTOTLE. Poetics. Translated by Stephen Halliwell. Cambridge: Harvard University Press, Loeb Classical Library, 1995.
} 
gismo (e veremos como prosopopeia e dialogismo se misturam como dispositivos do discurso dramático), nos textos dos capuchinhos franceses, por exemplo, a matriz discursiva que organiza esses discursos é claramente diegética, o que Andrea Daher deixa claro em seus livros. É justamente o modo diegético dominante, narrativo, o que permite aos narradores, ao mudar de modo, produzir o efeito de incrível presença dos caracteres a que cedem a palavra e a que emprestam ação: a dicção que se passa a ouvir, sabe-se, não é a dos narradores, porque estes narravam em francês e agora falam os outros, os índios, e a prosopopeia significa fazer soar a voz de outro, e, com ela, uma outra personalidade (em suma, há personificação). Sabe-se pelo estudo de incontáveis retóricas dos séculos XVI e XVII que Aristóteles, na Poética, ao discorrer longamente sobre a ação, afirmava que a ação é constituída de pequenos atos e que estes se tornam manifestos como exteriorização de pensamento, na fala das personae. Como sabemos pela Politica e pela Retórica aristotélicas que homens não falam como mulheres, velhos como meninos e senhores como escravos, é justamente a alternância de vozes caracteriais no drama e em todos os gêneros poéticos e apoéticos que efetua o distinguo ou distinção da caracterização: nos relatos estudados exemplarmente por Andrea Daher, sabemos que a voz narrativa é efetuada em uma dada língua, mas quando se muda não apenas o modo de imitar (de diegese para mimese), mas a língua da própria imitação, do francês para o tupi, produz-se intensa vividez na representação, porque não há mais a interposição de voz, a do narrador, que sempre significa pelo menos um grau de afastamento em relação ao caractere representado, sobretudo quando o que fala, fala em francês de um mundo outro, que pode supostamente significar-se sem a precisão da intermediação: o índio fala. Mas não nos esqueçamos que a prosopopeia não é apenas uma ficção da voz, é também uma ficção da corporeidade do caractere que tem de ser personificado por quem toma seu lugar. Nas escolas jesuíticas das Monarquias Ibéricas esses exercícios preliminares ou progymnasmata eram difundidíssimos e davam-se muita vez na forma de embates de tipo dialógico. Mesmo que ninguém se pusesse no lugar do índio ao proferir ou ler em voz alta seu discurso, sabia-se, porque fruto de uma prática escolar, qual era o vazio a ser preenchido. $\mathrm{O}$ corpo que fala nos discursos, elemento da prática da sermocinação, não é um corpo em estase, como na pintura, especificamente, na arte do retrato, é um corpo cinético cujos estados patéticos, no entanto, só podem corresponder às muitas doutrinas sobre a actio, o que faz com que esse corpo só se torne presente, no entanto, quando é capturado pela modelização dos afetos que várias artes do tempo, como gramática, poética, e retórica lhe impóem. Nos padres capuchinhos, a amplificação do efeito de presença também se dá pelo uso, estudado por Andrea Daher em vários de seus escritos, do tempo verbal: sabe-se por Aristóteles ${ }^{47}$, por Cícero $^{48}$ e por Quintiliano ${ }^{49}$ que o tempo presente do

\footnotetext{
${ }^{47}$ Cf. ARISTOTLE. Poetics. Op. cit.

${ }^{48}$ Cf. CICERO. De inventione, De optimo genere oratore, Topica. With an English Translation by H. M. Hubbell. Cambridge: Harvard University Press, Loeb Classical Library, 1993.

${ }^{49}$ Cf. QUINTILIAN. The Institutio Oratoria. With an English Translation by H. E. Butler. In four volumes.
} 
modo indicativo é aquele que intensifica mais do que os outros o efeito de evidência e é por isso que, mesmo quando a seçáo narrativa de relatos franceses nos introduzem o caractere a falar como se esse ato de fala fosse temporalmente passado, efetuam-no linguisticamente no presente de uma elocução que se póem diante de nossos ouvidos com toda sua estranheza. O tempo passado do verbo que refere o dito, o dictum, capturado como fala e ação, é fruto sempre de uma autópsia e essa evidência do testemunho só pode encontrar um correspondente à altura ao mudar-se do modo diegético para o modo mimético e do tempo passado para o tempo presente: o que se viu tem ainda de dar-se a ver porque essa suposta equivalência é resultante de uma suposta verdade, a da familiaridade com os índios e o fato de vê-los e ouvi-los. O ouvido é tão soberano nas modalidades francesas de conceber a autópsia, distante dos modos ibéricos de a produzir, que neles se efetua uma grande descoberta de Andrea Daher: neles diz-se: "o índio falou" e ele imediatamente póe-se a falar. Pode-se pensar que é muito pouco essa "inteligência", o entendimento dessa modalidade de representação, mas ela não o é absolutamente. Que coisas muitas estão implicadas nessa modalidade? A primeira delas, e que tem impacto imediato sobre a própria verossimilhança da representação, é a de que o índio fala porque quer falar somente o que fala. Mesmo que haja uma traduçáo posterior do que fala, o texto de partida é o suposto ato de fala do índio e não o contrário. Para se ter uma ideia do alcance e do impacto em termos de significação histórica da operação tradutória, comum nos séculos XVI, XVII e XVIII no mundo americano, e que se efetua por diferentes modalidades, vamos nos deter um pouco sobre a prática de composição e uso de catecismos por padres da Companhia no Novo Mundo. Nos catecismos e oraçóes traduzidos para uso mais dos missionários do que os índios, os discursos modelares são sempre portugueses ou espanhóis, latinos muita vez, vertidos para o tupi. O índio dos catecismos, quando fala, só o faz para responder a perguntas que the são apresentadas pelo catequista, que ele muita vez já sabe, ou, se não sabe, tem de inscrevê-las bem em si a ponto de sempre saber a resposta apropriada a cada pergunta que lhe é feita: a memorização da chamada sequência é o resultado desejado pelo catequista e supostamente pelo catecúmeno. Nesse processo de verdadeira captura do corpo do destinatário índio, o que se visa é transformá-lo, como disse muitas vezes João Adolfo Hansen ${ }^{50}$, Alcir Pécora ${ }^{51}$ e a própria Andrea Daher ${ }^{52}$, "em um veículo para a fala da alma católica", procedimento recorrente em escritos jesuíticos, com vário grau de sucesso e com importantes inflexôes inclusive na imitação de um pneuma cristão que ritmaria a fala índia, se pensar-

Cambridge: Harvard University Press, Loeb Classical Library, 1963.

${ }^{50}$ Cf. HANSEN, João Adolfo. Anchieta: Poesia em tupi e produção da alma. In: ABDALA JR., Benjamin \& CARA, Salete de Almeida (Orgs.). Moderno de Nascença: figuraçôes críticas do Brasil. São Paulo: Boitempo, 2006.

${ }^{51}$ Cf. PÉCORA, Alcir. Vieira e a condução do índio ao corpo místico do Império Português (Maranhão, 1652-1661). In: COSTIGAN, Lúcia Helena (Org.). Diálogos da conversão. São Paulo: Edusp, 2005, p. 83-98.

${ }^{52}$ Cf. DAHER, Andrea. O Brasil francês. Op. cit. 
mos na ideia central de número que ordena toda a poesia, e, inclusive, os catecismos e oraçóes de que falamos. O próprio respiro indígena estaria contaminado pelo pneuma europeu da numerização do discurso regrado por gramática, poética e retórica. Um elemento sobressai ao lermos os catecismos: a dificuldade que se sabia existir para traduzir os modelos europeus para as línguas indígenas, embaraçadíssimas, como diziam, por exemplo, Antônio Vieira e Vincêncio Mamiani ${ }^{3}$, mas que, depois de desenoveladas pela arte gramatical que lhe dava ordem, prestavam-se a que se compusessem com elas os modelos europeus. Mesmo que do ponto de vista do resultado alcançado sempre tenhamos índios apropriados por práticas de discurso diversas, e mesmo que, como nos diz Andrea Daher, nos textos franceses há "a figura de um Tupinambá convertível, dotado de palavra para expressar, em sua língua, seu desejo de conversáo e de aliança com os franceses" ${ }^{\text {, }}$, uma coisa é o índio dizer, sobretudo como o diz, o que deseja, e outro é atender às injunçôes do catecismo, com seu elenco de perguntas e respostas. No caso dos diálogos catequéticos de Mamiani, o acordo se dá entre o índio catecúmeno e o padre catequista, sendo a cena de enunciaçáo das verdades da fé a superação das trevas da língua, que articula o saber da doutrina e a fé em Deus, e só por poder fazê-lo é língua. O efeito é muito outro no caso dos discursos em tupi nos relatos franceses: mesmo que pensemos que é a convertibilidade que assegura a humanidade do índio, é o reconhecimento da capacidade de falar do índio, que nos soa como pura matéria sonora em sua estranheza, o que torna vívida a sua presença e autêntica a autópsia, que os padres presenciam e notam, que lhe assegura um estatuto diverso ao daqueles que nada dizem, porque só dizem o consabido da fala esquemática do catecismo. Nos diálogos catequéticos de Mamiani, estão ausentes os elementos próprios da diatribe, pois neles não há possibilidades polêmico-dogmáticas, como aquelas encenadas no Diálogo da Conversão do Gentio, de Manuel da Nóbrega. Se, como diz Alcir Pécora relativamente ao citado Diálogo de Nóbrega, a "eficiência persuasiva particular do diálogo" depende dele "constituir-se discursivamente como uma dramatização da vitória argumentativa sobre o oponente, obtida no interior de um dispositivo que encerra ou prescreve etapas sucessivas de combate intelectual" nos escritos de Mamiani, por outro lado, o índio dócil, que responde com correção às perguntas doutrinárias, já supõe a superação das "etapas sucessivas do combate espiritual" e propõe a efetuação do locus derivado de Nóbrega do índio como página em branco, em que se inscreve com facilidade o ditado dos padres, figuraçáo essa mais fundada na esperança do que atendida por uma prática catequética que, desde o século XVI, tropeçou em inúmeros percalços. A simplicidade elocutiva dos diálogos catequéticos mimetiza o tom pedestre da fala dialogada (pensando-se é claro no pedestrianismo genérico do que se escreve em portu-

\footnotetext{
${ }^{53}$ Cf. MAMIANI, Luís Vincêncio. Catecismo da doutrina cristã na língua brasílica da Nação Kiriri. Lisboa: Miguel Deslandes, 1698.

${ }^{54}$ DAHER, Andrea. A oralidade perdida. Op. cit., p. 23.

${ }^{55}$ PÉCORA, Alcir. Vieira e a condução do índio ao corpo místico do Império Português (Maranhão, 16521661). Op. cit., p. 97.
} 
guês) e finge ao mesmo tempo o índio como infans, aquele que aprende a falar, pois de fato o que fala nos diálogos é algo novíssimo para ele. Sforza Pallavicino, ao citar uma crítica de Pico della Mirandola aos escritores sacros que sobrecarregavam suas composiçóes de ornatos, afirmava que estes diminuem o grau de credibilidade do discurso, pois nas coisas santas a eficácia persuasiva deve derivar das razóes, mas não dos artifícios ${ }^{56}$, ou seja, para a verdade revelada, justamente por ser verdade, é requerida uma maneira semplice e piana de exposição ${ }^{57}$ :

As razóes de Pico se reduzem ao seguinte: ao tratar-se de eloquência, os ornamentos diminuem a crença na verdade, e a tornam incerta; o leitor duvida se a força que sente se deve ao intelecto, deriva da eficácia das razóes, ou dos artifícios do escritor: porque nas Escrituras Sacras Deis quis um estilo simples e chão com o qual converteu ao mundo..$^{58}$

É preciso ainda dizer uma coisa sobre a operação tradutória: se como nos dizem Vieira e Mamiani, as línguas dos índios são tăo embaraçadas que é preciso pôr o ouvido junto à boca do falante para tentar capturar as letras, uma a uma, sempre com auxílio de línguas, se aquilo que se enreda em primeiro lugar é o som, que escapa das malhas da escuta e que se esforça por ser apenas ruído, se a phoné recusa-se à domesticação da arte gramatical e das artes do discurso, os livros franceses dos simpáticos padres, ao tempo em que nos apresentam o Tupinambá em sua suposta liberdade, atestam seu cativeiro ao nos introduzir em seguida seu equivalente francês, testemunho de sua captura.

Como dissemos, que o poeta possa imitar o que imita de modos distintos, é porque pode com o mesmo meio, a linguagem, operar só com narrativa, só com discurso direto, ou pode ainda combinar narrativa e discurso direto; o que há na base da imitação, sempre, é ação, mas são também caracteres, como nos ensina Aristóteles, o que torna o ethos elemento

\footnotetext{
${ }^{56}$ Há uma outra importante passagem no tratado de Sforza Pallavicino, em que se produz uma contundente crítica do excesso elocutivo, com ênfase no emprego de metáforas arditte: "Poichè il dire, che la verità è tanto bella per sè medesima, che ogni straneo liscio le imbratta e non le adorna le guancie; che alla sua onestà disdicono tutti i belletti; e mille simiglianti dettati; è vn voler appunto imbellettar con metafore la bugia perche apparisca verità à gl'ingegni di poca vista" (PALLAVICINO, Sforza. Considerazioni sopra arte dello stile, e del dialogo. Roma: Eredi del Corbelleti, 1662, p. 36).

${ }^{57}$ Alcir Pécora, ao estudar o Diálogo da Conversão do Gentio, de Nóbrega, cita preceito de Demétrio em que se distingue a fala coloquial (sermo) da formal (contentio), sendo a primeira própria do gênero dialogal (PÉCORA, Alcir. A conversão pela política. In: Máquina de gêneros. São Paulo: Edusp, 2001, p. 91115 [p. 97]), preceito esse que é reciclado por Pallavicino como vimos acima. Contudo, como afirma Alcir Pécora, entre os letrados dos séculos XVI e XVII, "o diálogo é sobretudo discurso que evidencia uma prática civil, cortês e espiritualmente refinada, sem ser professoral ou especializada, cujo modelo histórico máximo certamente se formula n'O Livro do Cortesão, de Castiglione" (Ibidem, p. 97-98), o que diferencia a proposta desse tipo de diálogo daqueles de Mamiani.

${ }^{58}$ PALLAVICINO, 1662. Op. cit., p. 24. No original: Le ragioni del Pico si riducono alle seguenti: che se tratassi dell'eloquenza, gli ornamenti di lei tolgon la fede alla verità, e la rendono incerta; mentre il lettore dubita se la forza che sente farsi all'intelletto, deriui dall'efficacia della ragione, ò dall'artificio dello Scrittore: Perciò nelle Sacre Lettere haver Dio voluto vno simplice stile e piano, col quales'è convertito el mondo.
} 
central em qualquer reflexão posterior a Aristóteles sobre imitação. $\mathrm{O}$ ethos torna-se elemento axial de gêneros pictóricos, como o retrato, nos séculos XVI e XVII, em que expressão facial, evidência da caracterização pelo patético que articula a configuração, alia-se ao restante do corpo, falante em sua mudez, sobretudo quando vestido de sua segunda pele, a roupa. No retrato não há propriamente ação, mas a potência derivada do ânimo. No retrato dá-se a máxima modelização da corporeidade do corpo, porque nele não há ação ou narrativa, conquanto se possa dizer que as doutrinas sobre a representação do corpo cinético no drama ou do corpo em estase no retrato já se fizessem presentes em preceptivas como a Retórica ${ }^{59}$ e a Poética, ao tratar-se da relação entre orador e actio e entre ator e performance. Aristóteles, ao falar da relação entre imitação e pintura, na Poética, afirma que "gostamos de contemplar a mais precisa imagem das coisas, mesmo daquelas cuja vista real nos causa repulsa" ${ }^{\prime \prime 0}$, como cadáveres; e completa a asserção prévia ao dizer que "os homens gostam de olhar imagens porque por meio de sua contemplaçáo eles entendem o que cada elemento constituinte significa, e podem, por exemplo, dizer 'essa pessoa é assim e assim"'61. O que isso significa exatamente? Como se pode dizer, pela pintura, pelo retrato, que uma pessoa seja assim e assim?

Aby Warburg, impactado pela teoria evolucionista de Charles Darwin, tentou compreender a transmissão filogenética das condutas e das expressôes faciais nos animais superiores e no homem; por meio da combinação da teoria darwiniana e do conceito de "memória” emprestado da psicologia fenomenológica de princípios do século XX, propôs que nas artes representativas, como pintura e escultura, a expressão de estados patéticos poderia ser remontada à noção de "engrama": "conjunto estável e reforçado de marcas que determinados estímulos externos imprimiram na psique e que produz respostas automatizadas quando da reapariçáo desses mesmos estímulos" ${ }^{\prime 2}$. As expressôes patéticas, presentes nas artes da representação desde gregos e romanos e recicladas nas artes europeias dos séculos XV, XVI e XVII, não poderiam, segundo Aby Warburg, ser compreendidas como meros costumes artísticos, como resultante de corpos de doutrina e preceituação $0^{63}$. O que importa por ora salientar é justamente como a apropriação dos engramas, o que implica sua interpretaçáo modelizadora e consequente representação, fruto de uma técnica artística que se torna costumeira, pode ser estudada no âmbito de doutrinas fundadas na mimesis: é necessário levar a termo uma análise da Poética, da Retórica e da Ética a Nicômaco, de Aristóteles, para além das muitas apropriaçóes que houve delas nos séculos XVI e XVII, com o objetivo de entender a relação entre representação e caracteres agentes, de um lado, e, de outro, como na

\footnotetext{
${ }^{59}$ Cf. ARISTOTLE. Rhetoric. Translated by John Henry Freese. Cambridge: Harvard University Press, Loeb Classical Library, 1994.

${ }^{60}$ ARISTOTLE. Poetics. Op. cit., p. 37.

${ }^{61}$ Ibidem, p. 39.

${ }^{62}$ BURUCÚA, José Emilio. Historia, arte, cultura. De Aby Warburg A Carlo Ginzburg. Buenos Aires: Fondo de Cultura Económica, 2005. p. 28.

${ }^{63}$ Cf. Idem.
} 
própria ideia de caracteres (drontes, agentes do drama), de base ética, está implicada uma poética caracterial da face, do corpo em ação, e uma retórica das afecções corporais. Se os engramas já modelizados por artes como poética e retórica são formas sociais partilhadas de cognição, que possibilitam, pelo conhecimento do traço patético correspondente à afecção que o ocasionou, o reconhecimento do pathos expresso como "expressão", porque já formalizado de acordo com convençóes de gênero, estilo e decoro, seria nele, no engrama, que precisaria manter-se radicada toda representaçáo para provocar no espectador a resposta biológica que se tem frente a um mesmo estímulo? Heinrich Wölfflin acreditava que, em termos estilísticos, o efeito de quadros sobre quadros era mais relevante do que a adesão à natureza propriamente dita ("the effect of picture on picture as a factor of style is much more important than that comes directly from the imitation of nature" "64). Ernst Gombrich também declara que a imitação de matrizes artísticas é mais relevante do que a empiria ${ }^{65}$. Pode-se dizer que nos séculos XVI e XVII várias artes, como a escultura sacra e a pregação, tinham como uma de suas finalidades não apenas manter viva a memória dos engramas já modelizados, mas encontrar meios de produzir a intensificação de respostas passionais à inscrição desses engramas por meio da amplificação dos recursos artísticos que operavam sua representação. Importa dizer que a modelizaçáo das afecçôes produz crescentemente um distinguo, fruto da operação de notação: os livros de Andrea Daher ensinam-nos que é justamente de notação que se fala quando se lê o livro do padre Claude ou aquele de Yvres d'Evreux: as falas dos tupinambás são notatio, são fruto de notação: esta, ao efetuar a lexis, a palavração dos índios em discursos gramaticalmente e retoricamente modelares, só podem fazê-lo a partir de operaçôes análogas que fazem falar os caracteres do drama e do poema heroico em geral, por exemplo. Atendo-nos ainda à prosopopeia e à leitura da Retórica, de Antoine Fouquelin, este nos ensina que a prosopopeia pode ser plena ou perfeita, ou oblíqua e quase muda. Que modalidades seriam essas e como se efetuariam em termos discursivos? A prosopopeia chamada plena quando "toda a ficção é representada por nossa ação" ${ }^{\text {", }}$ da qual há dois distintos modos, um em que a prosopopeia é inteira e contínua, e outro, em que é cortada ou interrompida. A prosopopeia contínua é aquela em que a ação por nós empreendida quando da personificação ou imitação de caráter agente tem um propósito que não sofre interrupção, podendo haver - o que é desejável - um preâmbulo que sirva de introdução ao discurso, para que se entenda que o procedimento é natural na ordem do discurso em que comparece e que não foi levado a termo de forma desarrazoada e temerariamente. Sabe-se, desde Aristóteles, que os discursos retoricamente regrados se estruturam a partir da dominância de tempos verbais específicos a depender do gênero a que pertencem: o passado é próprio do judiciário,

\footnotetext{
${ }^{64}$ WÖLFLLIN, Heinrich. Principles of Art History. New York, Dover, 1950. p. 250.

${ }^{65}$ Cf. GOMBRICH, Ernst. Art and Illusion. A Study in the Psychology of Pictorial Representation. Princeton: Princeton University Press, 1989.

${ }^{66}$ FOUQUELIN, Antoine de. La rhetorique françoise d'Antoine Foclin de Chauny en Vermandois [...]. Paris: André Wechel, 1555. p. 86.
} 
o futuro, do deliberativo, e o presente, do demonstrativo ou epidítico; mais, aprendemos com Aristótles, em sua Retórica, com os retores antigos e com aqueles dos séculos XVI e XVII que o tempo presente intensifica o efeito de visualização da ação, incrementa a enargeia ou illustratio do discurso e que a intensificação da energeia pelo verbo no tempo presente maximiza a enargeia ou efeito de visualização da ação: como toda convenção da ordem do discurso, só se pode entender os efeitos em termos de sentido dessas convençóes estudando-se todas elas, que é o que faz Andrea Daher e sua arqueologia de dispositivos textuais: em seus livros, aprendemos que os discursos diretos são próprios dos textos franceses em oposição aos textos portugueses, em que não há o mesmo procedimento prosopopeico, o que é certo; com ela entendemos também que o presente do verbo na personificação é recurso que incrementa a substituição da voz do narrador, forma de mediação anterior ao discurso direto, que produzia grau de distanciamento frente àquilo que diretamente nos é exposto pelo recurso à prosopopeia. A prosopopeia plena pode ainda se nos apresentar na forma de dialogismo, quando mais de um caractere é fingido ao mesmo tempo, o que exige do orador e do poeta mais fôlego, já que é preciso construir cada caracterização por meio de uma fala ou lexis que seja a "expressão" modelar desse caráter. O que aprendemos com Andrea Daher é que os discursos dos Tupinambá, por serem compostos na língua geral, por serem estranhos, ou seja, estrangeiros aos leitores franceses a que se destinam, se apresentam a esses leitores como pura phoné, som ruído, pura fisicalidade ou massa sonora, que intensifica muitíssimo o efeito de presença já ressaltado pelo verbo no tempo presente e pelo procedimento prosopopeico. Todos esses elementos em conjunto produzem a maximização do estranhamento, que é efeito visado pelos padres, que compóem os livros, articulando-os, as suas seçôes, objetivando a totalidade de efeito de sentido do todo pela observação da partitio ou partição do todo, considerando-se sempre em termos sintagmáticos, por que a ordem do discurso é temporal, um antes e um depois. Foi a partir do estudo de Andrea Daher que eu me propus estudar os catecismos bilíngues produzidos por missionários portugueses nos séculos XVI e XVII, com o objetivo de contraditar as suas hipóteses, o que me levou a um melhor entendimento desse gênero, táo mal estudado entre nós, e, ao mesmo tempo, à certeza de que os dispositivos estudados por Andrea Daher em textos franceses do século XVII eram de fato próprios desses textos. Uma primeira diferenciação tem de ser feita logo de cara: os diálogos são espécie de discurso puramente mimético e de tipo dialogal, em que um texto matricial em língua portuguesa, o catecismo, é traduzido zelosamente por padres para em seguida inculcá-lo nos índios que são dotados de alma; o estranhamento do tupi é elidido pela operação tradutória, pois a ordem lógico sintagmática e lexical depende de uma outra, que fala a verdade da escritura e dos dogmas da fé; nos textos estudados por Andrea Daher, a tradução francesa não se quer um sucedâneo do texto tupi, mas apenas espécie de entendimento dele; o texto tupi, proferido por um índio, não é dado ao índio para que ele internalize verdades que estão além de sua língua e que são integrados à sua ordem linguística para inclusive torná-la melhor do que fora até o momento em que se deixa contaminar por esses 
elementos. A fala do índio nos livros dos padres Claude e Yves são ruído que, a despeito de sua posterior interpretaçáo pelos padres, elide em parte seu caráter de puro som, permanece como elemento sonoro próprio da proferição. A ilusão nos livros dos padres Claude e Yves é que a fala das personagens que discursam é anterior a qualquer operação que lhes dê sentido; é ato livre e não subordinado à ordem do discurso, pensando-se essa ordem em seus condicionantes gramaticais, retóricos, poéticos etc. A diferença nos dispositivos textuais pode apontar, é claro, para diferentes efeitos de sentido das representaçóes: se pensarmos que os índios que falam na prosopopeia dos textos franceses o fazem sem coação, sem a imposição de um jugo, e que falam livremente para dizer que aquiescem com os projetos do Estado francês e da Igreja, essa suposta liberdade é intensificada pela liberdade linguageira de uma língua quase selvagem; nos textos portugueses, por outro lado, a língua tupi comparece totalmente assujeitada por um conjunto de técnicas de dominação, a da gramática, a do catecismo e ela se articula soando-se a si mesma somente e na medida que soa outra de si, falando de verdades que são suas porque domesticaram a fala outrora selvagem e outra; quando os índios portugueses dos catecismos rezam o Pai Nosso e respondem às perguntas dos catequistas, fazem-no assujeitados no lugar de catecúmenos e já se integraram ao grêmio da catolicidade contrarreformista.

Marcello Moreira

\section{Referências}

ARISTOTLE. Rhetoric. Translated by John Henry Freese. Cambridge: Harvard University Press, Loeb Classical Library, 1994.

. Poetics. Translated by Stephen Halliwell. Cambridge: Harvard University Press, Loeb Classical Library, 1995.

BURUCÚA, José Emilio. Historia, arte, cultura. De Aby Warburg A Carlo Ginzburg. Buenos Aires: Fondo de Cultura Económica, 2005.

CERTEAU, Michel de. A escrita da história. São Paulo: Forense Universitária, 2015.

CICERO. De inventione, De optimo genere oratore, Topica. With an English Translation by H. M. Hubbell. Cambridge: Harvard University Press, Loeb Classical Library, 1993.

CLAUDE D'ABBEVILLE. Histoire de la mission des peres capucins en l'isle de Maragnan et terres circonuoisines [...]. Paris: François Huby, 1614.

DAHER, Andrea. O Brasil francês. As singularidades da França Equinocial, 1612-1615. Rio de Janeiro: Civilização Brasileira, 2007.

- A oralidade perdida. Ensaios de história das práticas letradas. Rio de Janeiro: 
Civilização Brasileira, 2012.

FOUQUELIN, Antoine de. La rhetorique françoise d'Antoine Foclin de Chauny en Vermandois [...]. Paris: André Wechel, 1555.

GOMBRICH, Ernst. Art and Illusion. A Study in the Psychology of Pictorial Representation. Princeton: Princeton University Press, 1989.

HANSEN, João Adolfo. Anchieta: Poesia em tupi e produção da alma. In: ABDALA JR., Benjamin \& CARA, Salete de Almeida (Orgs.). Moderno de Nascença: figuraçóes críticas do Brasil. São Paulo: Boitempo, 2006.

LESTRINGANT, Frank. O canibal: grandeza e decadência. Brasília: Editora UnB, 1987.

MAMIANI, Luís Vincêncio. Catecismo da doutrina cristã na língua brasílica da Nação Kiriri. Lisboa: Miguel Deslandes, 1698.

PALLAVICINO, Sforza. Considerazioni sopra arte dello stile, e del dialogo. Roma: Eredi del Corbelleti, 1662.

PÉCORA, Alcir. A conversão pela política. In: - Máquina de gêneros. São Paulo: Edusp, 2001, p. 91-115.

- Vieira e a condução do índio ao corpo místico do Império Português (Maranhão, 1652-1661). In: COSTIGAN, Lúcia Helena (Org.). Diálogos da conversão. São Paulo: Edusp, 2005, p. 83-98.

QUINTILIAN. The Institutio Oratoria. With an English Translation by H. E. Butler. In four volumes. Cambridge: Harvard University Press, Loeb Classical Library, 1963.

WÖLFLLIN, Heinrich. Principles of Art History. New York, Dover, 1950.

YVES D'ÉVREUX. Voyage dans le Nord du Brésil fait durant les années 1613 et 1614 [...]. Avec une introduction et notes par M. Ferdinand Denis. Leipzig et Paris: Librairie A. Franck, 1864." 
Magnífico Reitor da UFRJ, professor Roberto Lehrer, Senhor Decano do Centro de Filosofia e Ciências Humanas, professor Marcelo Correia e Castro, Senhora Diretora do Instituto de História, professora Norma Côrtes:

É, de fato, muito bonito ser homenageada. É uma honra que autoriza muitas outras, como bem mostra esta cerimônia.

A primeira dessas honras foi a de poder escolher, para compor a solenidade, o melhor dos melhores oradores, José Murilo de Carvalho, que também vem a ser o melhor dos melhores historiadores, $\mathrm{e}$ - por sorte minha ou por afinidade eletiva nossa - o melhor dos melhores amigos.

É honra também poder discursar a todos os presentes, para dizer-lhes o quanto reconheço o privilégio que foi ter tido os alunos e orientandos que tive, e receber, como retorno, o reconhecimento dos próprios pares.

Neste dia de muitos privilégios, para estar ao meu lado, me foi dada a honra também de escolher uma comitiva, e de me fazer acompanhar por João Fragoso, por Marco Antonio Gonçalves e por José Almino de Alencar. Só fui entender depois a conveniência da escolha que fiz, comandada antes pela admiração e pelo afeto. Joáo é da história, de onde sou eu também. Marco Antonio é da antropologia, por onde sempre trafeguei. E José Almino é da sociologia, que oferece o desenho para o meu modo de pensar. Mas Almino é também da poesia: a poesia que me permite, que sempre me permitiu, imaginar, ver fora.

Se há mérito reconhecível nessas minhas pertenças e preferências, talvez ele consista, no fundo, no simples fato de serem as de uma leitora. Não houve uma só aula dada, um só livro escrito, um só debate travado em que eu náo tenha buscado o gesto de ler.

Foi com o grande leitor que foi Michel de Montaigne que inaugurei, muito cedo, o meu modo próprio de ler, ao encontrar nos Ensaios um conjunto intenso de memória, de julgamento moral e de emoçáo provocados pelos livros da biblioteca em que ele se deixou praticamente exilar. É assim que ele se refere à sua "frequentação dos livros": "Para me distrair de uma ideia inoportuna - escreve ele -, nada melhor do que recorrer aos livros; eles me demovem facilmente na direção deles e a levam embora. E também nunca se revoltam por eu os procurar apenas na falta de outras comodidades mais reais, mais vivas e naturais; eles me recebem sempre com a mesma cara."

Os termos fabulosos de Montaigne, que atribuem açáo, sentimento e "cara" aos livros, são suficientes para que eu não vá além do meu gosto pela leitura dos Ensaios. Evito assim um desfile de nomes de autores e títulos de livros e deixo livre curso à imaginação de vocês, ouvintes, do muito que li, desde essa cena primitiva na biblioteca de Montaigne, em que estive por delegação tantas vezes.

No desejo de me filiar ao leitor que foi Michel de Montaigne, diluo estrategicamente as formas mais convencionais de memória autocomemorativa. Tampouco deixo a minha pró- 
pria memória ir em busca de uma origem num assento biográfico, e assim não faço carregar tanto o peso da minha subjetividade, que mantenho aqui, até certo ponto suposta, mas não totalmente revelada na imagem da leitora que sou.

É justamente por esse traço de frequentadora de livros que posso considerar, hoje, que não foi um acaso ter sido acolhida, na década de 80, pelo historiador Roger Chartier, na Escola de Altos Estudos em Ciências Sociais, com um projeto de tese muito próximo da história do livro e das práticas de leitura da época moderna que ele praticava e até hoje pratica: um estudo de caso aplicado a um conjunto de narrativas francesas sobre o Brasil do começo do século XVII.

Por inúmeras vezes, tive nas mãos os exemplares dos relatos dos missionários franceses enviados ao norte do Brasil junto aos índios tupinambá, publicados entre 1612 e 1615, em ediçôes luxuosas e autorizadas por privilégio real. Por inúmeras vezes, imaginei um leitor francês que, ao folhear um desses livros, se deparasse com páginas inteiras cobertas de discursos em língua tupi, impressos em itálico. Nesse lugar imaginado de um leitor estarrecido diante do exótico, do que vem de fora, entendi a verdadeira operação de "conversão linguística", que permitia, no interior do próprio livro, passar dos caracteres itálicos aos romanos, e assim do tupi, na sua pura oralidade, à escrita ocidental. Ao folhear, mais além, as páginas desses exemplares, velhos de mais de três séculos, vi as imagens de três índios nus seguirem-se de imagens de três índios conversos e vestidos à francesa, tal como foram dadas a ver aos leitores (ou até mesmo aos muitos iletrados) que manuseassem esses livros, na França do começo do século XVII.

Com esses livros nas mãos, treinei, portanto, o meu esforço de extrair camadas de sentido da leitura desses discursos. Pude assim ouvir uma oralidade indígena desde então irremediavelmente perdida, porém visivelmente reconquistada em páginas impressas.

Pelo visto, a leitora que sou elegeu precisamente a leitura e a escrita, em sua interface com o oral, como objetos de trabalho, como temas de aulas e seminários, como instrumentos de pesquisa, sempre mergulhada na filigrana dos textos. Ao fazer história, procurou dar conta justamente de como se liam (ou se ouviam) os discursos de um passado de que resta hoje apenas a matéria arruinada em alguns vestígios, mas cujo funcionamento em seu tempo pode muito bem ser conhecido a partir deste nosso presente.

Foi assim que os anos de pesquisa cotidiana na velha Biblioteca Nacional de Paris da rue de Richelieu imprimiram, na vontade profissional que já era a minha, o ritmo do meu perpétuo hábito de ler e o sentido de avançar firme numa direção, como exige toda investigação. Tive a sorte, depois, de estar imersa nos incríveis arquivos da Sociedade de Jesus, em Roma, no Arquivo Histórico De Propaganda Fide e no Arquivo Secreto Vaticano; no Arquivo Geral de Simancas, na Espanha, na Torre do Tombo, em Portugal, e mais cotidianamente nas Bibliotecas Nacionais de Paris e do Rio de Janeiro: um privilégio sem fim. Esses terão sido os melhores momentos de trabalho de que tenho memória, náo apenas pela riqueza dos livros 
e papéis que essas instituiçóes oferecem, e que corresponde ao meu gosto mais íntimo da investigação, mas justamente pela memória do silêncio e da repetição cotidiana de gestos que convêm perfeitamente ao meu temperamento, confesso, obsessivo.

Mas o que faz hoje, aqui, esta leitora de toga?

Diante de colegas e amigos, hoje, mostro a minha pertença - como a de muitos de nós - à espécie homo academicus. Carrego com isso, legitimamente, a tradição da instituição de que faço parte e me deixo definir dentro dos padróes estritos do saber que produzo, que reproduzo e que defendo. O homo academicus, duramente definido por Pierre Bourdieu, é aquele que exalta a seriedade universitária como "instrumento de normalização que tem para si todas as aparências, as da ciência e as da moral."

Decerto, esse homo academicus se encontra no extremo oposto da definição de uma outra espécie de que todos participamos, a do homo ludens. Tal como pensado pelo historiador holandês Johan Huizinga, o homo ludens é aquele que se livra à brincadeira, que joga, sendo o jogo a antítese aparente da seriedade.

Com toda evidência, o homo academicus é produtor de memória, de conhecimento, entre tantos produtos patrimoniais que exige legitimamente a atividade universitária; enquanto o seu oposto, ludens, diverte-se, joga, brinca, ri.

Mais de trinta anos antes de mim, alguém muito maior do que eu, Michel Foucault, já havia respondido da mesma forma a seus interlocutores, aqui mesmo no Brasil: "Quem sou eu? Um leitor." A simplicidade da fórmula e a imensidão de quem a enuncia, dão a pensar. Foucault é um leitor que ri, diria o historiador jesuíta Michel de Certeau: "Tomado pelo riso", "arrebatado por uma ironia das coisas", escreve De Certeau, "suas obras parecem ter todas a mesma origem: acessos de surpresa (como temos acessos de febre), formas jubilatórias súbitas, quase extáticas, surpresa ou maravilhamento que é, de Aristóteles a Wittgenstein, o momento instaurador da filosofia”.

Quando assim se instaura o pensamento no riso, o homo academicus e o homo ludens podem conviver, plenamente, sem se excluírem um ao outro.

Magnífico Reitor, caros colegas e alunos, queridos amigos e família, termino este discurso por um desejo: que este seja o meu mérito partilhado, o nosso mérito, construído na seriedade do trabalho acadêmico: o arrebatamento, a imaginação, a invenção. Deixemos sempre que se instalem, para que a nossa experiência intelectual seja maior e mais vital, e que possa até mesmo superar os tempos difíceis que por vezes se impóem. 